\title{
Deforestation Threaten Plant Biodiversity and Climate Change
}

\author{
Tamaz Patarkalashvili* \\ Technical University of Georgia, Center Studying Productive Forces and Natural Resources of Georgia, Georgia \\ *Corresponding author: Tamaz Patarkalashvili, Technical University of Georgia, Center Studying Productive Forces and Natural \\ Resources of Georgia, Georgia
}

\begin{abstract}
Forests biologically are the most diverse land ecosystems of our planet. Tropical forests for example cover just 7\% of the earth, but they support over half of all terrestrial plant and animal species. Forests still cover about 30 percent of total land area, yet, deforestation and forest degradation, including uncontrolled conversion of forest lands to agricultural use, continues at an alarming high rate in many countries of the world. Unlike some other resources, as: oil, coal, minerals etc. which considered exhaustible, forests fortunately have unique feature, in conditions of sustainable management they practically can be inexhaustible. That's why sustainable development should become the crucial direction of forest management in future. These and other problems and benefits that forests unselfishly provide to people are considered in the article.
\end{abstract}

Keywords: Forest benefits; Biodiversity; Environmental protection; Sustainable development; Greenhouse gases; Climate change

\section{Introduction}

Forests assure such environmentally critical functions as: biodiversity, water and soil conservation, water supply and climate regulation; Forests provide habitats to about two third of all species on the earth; In highland countries forests have extremely critical importance for minimizing ecological and environmentally diverse effects like: erosion, landslides, mud-torrents, rock-falls. They defend highlanders from strong, cold winds and avalanches. In mountain spar resorts they regulate rain and melted snow currents helping their slow penetration into ground. Therefore, maintaining stable mineral water outputs of these resorts. In arid environments forests are crucial to food security in dry seasons. Over $90 \%$ of 1.2 billion people living in extreme poverty depend on forests for some part of their livelihood. Half of the wood used in the world currently used for cooking, heat and light.

\section{Results and Analysis}

\section{Forests Different Roles and Benefits}

Forests play important role in water cycle by extracting ground water through roots and releasing it into atmosphere helping to create humid climate. In areas without forests water content in soil as well as in atmosphere reduces. Trees slow down the heavy raindrops falling on their leaves, branches and trunks helping to regulation of rainfall speed and its slow penetration into soil, reducing adverse effects of water erosion. Trees in forests and cities purify the atmospheric air by absorbing of different pollutants such as: nitrogen oxide, sulfur dioxide, ozone and particular matters. They absorb carbon dioxide - a greenhouse gas, which is the main contributor of global warming [1]. Deforestation is a major economic, social and environmental problem nowadays in the world. Forests help to mitigate land degradation and desertification by stabilizing soils, reducing water and wind erosion and maintaining nutrients in soils [2]. Forests are home for more than $80 \%$ of terrestrial biodiversity, providing them by habitats and food. They are hosting a wide variety of genetic resources on the earth. Forests provide useful wood products such as: round wood, that after processing into building materials or plywood products are used for furniture. Pulp of wood is used not only for paper and boxes, but for a wide variety of products including sponge. Among non-timber technical resources are bark, dyes, fiber, gums, incense, latex, oils, resins, shellac, tanning compounds and waxes, aromatic compounds for perfumery and cosmetic products, etc. [3]. Forests are source of food for many communities providing them with wild fruits, berries, mushrooms, nuts, medicinal and aromatic herbs, 
food additives: herbs, spices and condiments, aromatic plants, maple and birch trees' sap, honey, wild animals and birds' meat etc.

The last but not least and may be the most essential benefit that forests provide is oxygen that's necessary for all living organisms to stay alive. Among all terrestrial species only trees, bushes, grass, agricultural crops and vegetables produce oxygen through photosynthesis process, but the greatest amount of this oxygen come on threes with their huge foliage. Oxygen is also produced by Phytoplanktons that live near the water's surface and drift with the currents and marine plants: Cyanobacterium, or bluegreen algae and diatoms. Until now scientists of the world cannot agree which is the major contributor of oxygen to the atmosphere because it's very difficult to calculate. Some scientists believe, that amount of oxygen contributed by Phytoplanktons, Cyanobacterium and diatoms are between 50 to 80 percent. Others consider this correlation 50/50. It must be taken into account that about 70 percent of the Earth's surface is taken up by water, whereas area covered by forests is only 30 percent. So, the area of all marine plants (including Phytoplanktons) is about two times more than forests. Besides, forests not only produce oxygen, but also use themselves for breathing. On the forest's ability and amount of oxygen production adversely influence constant decrease of forests and their degradation. Consequently, decrease of forest area induce diminution of oxygen contribution to the atmosphere that negatively affected on all living organisms.

Table 1: Countries with Greatest Average Annual Tree Loss 2011-2013*.

\begin{tabular}{|c|c|c|}
\hline Rank & Country & Average annual tree cover loss 2011-2013(thousand hectares) \\
\hline 1 & Russia & 4,319 \\
\hline 2 & Canada & 2,450 \\
\hline 3 & Brazil & 2,157 \\
\hline 4 & United States & 1,736 \\
\hline 5 & Indonesia & 1,605 \\
\hline 6 & Dem. Rep. of the Congo & 608 \\
\hline 7 & China & 523 \\
\hline 8 & Malaysia & 465 \\
\hline 9 & Argentina & 439 \\
\hline 10 & Paraguay & 421 \\
\hline
\end{tabular}

Source: https:// global forest watch. Org 2018.

*Tree cover Loss Includes Both Permanent Deforestation and Temporary Cover Losses.

The leading country in greenhouse gas emissions from 2005 until now is China. It's GHG emissions from 2005 to 2014 increased from 6.9 G.T. to 12 G.T. Then come U.S and E.U. The least and stable GHG emissions in these years had only Canada and Mexico (Table 2). Presently there are about 390,900 plants known to science, of which about 369,400 are flowering. Over 96,000 species have been assessed for their conservation status with the latest update to the IUCN Red List. 96,951, including 27,514 plant species i.e. around $26 \%$ from them are threatened with extinction. Scientists believe that these threats come from climate change, habitat loss, diseases and invasive species. Climate change commonly refers to influences on climate resulting from human practices. Increases in the

\section{Forests Distruction and Biodiversity Loss Drives Climate Change}

Forests are the most important repositories of the terrestrial biological biodiversity. Tropical, temperate and boreal forests contain most diverse habitats for plants, animals and microorganisms. Forests' biodiversity provides variety of goods and services [4]. They play a vital role in daily life of the most rural communities in the world. They are the repositories of aesthetic, ethic, cultural and spiritual wealth for different religious groups in the world in spite of their confession. Unfortunately, forests area and biodiversity gradually diminish in the world for last decades. Deforestation and forest degradation through agricultural expansion, conversion of forest lands to pastures, infrastructure development, distractive loggings, wild fires and insect pests and diseases outbreaks, accelerate biodiversity and forest loss. World Economic Forum's Global Shapers Survey in 2017, climate change and destruction of nature placed on the first place with $48.8 \%$ [5] with nearly $20 \%$ of global greenhouse gas emissions, more than the entire global transportation, forest loss is the second largest contributor after energy sector (Table 1). The major GreenHouse Gases (GHG) in the atmosphere today are: Carbon dioxide $\left(\mathrm{Co}_{2}\right)$, Methane $\left(\mathrm{CH}_{4}\right)$, and nitrous oxide $\left(\mathrm{N}_{2} \mathrm{O}\right)$. less prevalent but very powerful greenhouse gases are hydrofluorocarbons $\left(\mathrm{HFC}_{\mathrm{s}}\right)$, perfluorocarbons $\left(\mathrm{PFC}_{\mathrm{s}}\right)$ and sulphur hexafluoride $\left(\mathrm{SF}_{6}\right)$. 
Table 2: Greenhouse Gas Emissions.

\begin{tabular}{|c|c|c|c|c|c|c|c|}
\hline \multicolumn{2}{|c|}{2000} & \multicolumn{2}{c|}{2005} & \multicolumn{2}{c|}{2014} \\
\hline Country & GNG & Country & GNG & Country & GNG & Country & GNG \\
\hline U.S. & 6.4 G.T & China & 6.9 G.T & China & 9.7 G.T & China & 12 G.T \\
\hline E.U. & 4.5 G.T & U.S. & 6.4 G. T & U.S. & 6.1 G.T & U.S. & 6.3 G.T \\
\hline China & 4.2 G.T & E.U. & 4.6 G.T & E.U. & 4.2 G.T & E.U. & 3.6 G.T \\
\hline Russia & 2.3 G.T & Russia & 2.1 G.T & India & 2.5 G.T & India & 3.2 G.T \\
\hline India & 1.6 G.T & Brazil & 1.9 G.T & Russia & 2.1 G.T & Indonesia & 2.5 G.T \\
\hline Brazil & 1.6 G.T & India & 1.8 G.T & Indonesia & 2.0 G.T & Russia & $2-0$ G.T \\
\hline Indonesia & 1.3 G.T & Indonesia & 1.7 G.T & Brazil & 1.5 G.T & Brazil & !.4 G.T \\
\hline Japan & 1.2 G. T & Japan & 1.3 G.T & Japan & 1.1 G.T & Japan & 1.3 G.T \\
\hline Canada & 720 M.T & Canada & 980 M.T & Canada & 910 M.T & Canada & 870 M.T \\
\hline Mexico & 610 M.T & Mexico & 700 M.T & Mexico & 740 M.T & Mexico & 730 M.T \\
\hline
\end{tabular}

Source: CAIT Climate Data Explorer. 2017. Country Greenhouse Gas Emissions. Washington, D.C. UNFCCC. 2017 Greenhouse Gas Inventory Data

It is obvious that in order to constrain the impacts of climate change within limits that the society will reasonably be able to tolerate the global average temperatures must be kept below two degrees Celsius. At the $48^{\text {th }}$ session of the IPCC (Intergovernmental Panel on Climate Change) in Incheon, South Korea, in 2018, was underlined that global warming is already reaching 1.5 degrees Celsius above pre-industrial levels. They warned that the planet is already on two/thirds of the way to there. Presently the average global temperature already increased on one degree Celsius. According to the report, the planet will reach this crucial threshold as early as 2030 based on the calculations of current levels of greenhouse gas emissions. The global net emissions of carbon dioxide would need to fall by $45 \%$ from 2010 levels by 2030 and reach net zero around 2050 in order to keep the warming around 1.5 degrees Celsius. But they also noted that even if warming will be able to keep at 1.5 degrees Celsius, the adverse impacts will be

\section{Forests' Threats}

Table 3: Summery of the data on forest species from the 25 countries.

\begin{tabular}{|c|c|c|c|c|c|c|c|}
\hline Pest type & Total & $\begin{array}{l}\text { In naturally re- } \\
\text { generated forests }\end{array}$ & $\begin{array}{l}\text { In planted } \\
\text { forests }\end{array}$ & $\begin{array}{l}\text { In both Types } \\
\text { of forests }\end{array}$ & $\begin{array}{l}\text { On broad- } \\
\text { leaves }\end{array}$ & On coni-ferrous & $\begin{array}{c}\text { On both host } \\
\text { types }\end{array}$ \\
\hline \multicolumn{8}{|l|}{ Indigenous Species } \\
\hline Insects & 277 & 102 & 135 & 39 & 178 & 80 & 18 \\
\hline Diseases & 46 & 7 & 30 & 9 & 34 & 8 & 4 \\
\hline Other & 22 & 14 & 7 & 1 & 14 & 5 & 3 \\
\hline Total & 344 & 123 & 172 & 49 & 226 & 93 & 25 \\
\hline \multicolumn{8}{|l|}{ Introduced Species } \\
\hline Insects & 64 & 3 & 49 & 12 & 28 & 34 & 2 \\
\hline Diseases & 28 & 2 & 22 & 4 & 17 & 6 & 5 \\
\hline Other & 9 & 7 & 1 & 1 & 5 & 1 & 3 \\
\hline Total & 101 & 12 & 72 & 17 & 50 & 41 & 10 \\
\hline Total all regions & 434 & 135 & 235 & 64 & 268 & 132 & 34 \\
\hline
\end{tabular}

Source: FAO, Global Review of Pests and Diseases. FAO, Forestry Paper. 156. Rome, Italy [21].

widespread and significant on many regions of the world. This goal will be impossible to achieve without reduction of emissions from the forest sector, in addition to other mitigation actions. The REDD+ (Reducing Emissions from Deforestation and Forest Degradation) program goes beyond deforestation and forest degradation and includes the role of conservation, sustainable management of forests and enhancement of forest carbon stocks. Forestry offers potential mitigation through sequestration in growing forests and use of forest biomass for bio-energy. There is potential for bio-fuels to reduce emissions from the transport sector. Reforestation can also contribute to mitigation of greenhouse gas emissions though sequestration of carbon from the atmosphere. Forests sequester carbon as they grow, until they reach maturity, after which carbon stock remains essentially constant unless they are disturbed by harvest or fire. The sequestration rate of planted forests depends on climate, soil factors and forest sustainable management. 
Forests have always been under different threats by variety of destructive natural disasters, like fires, hurricanes, droughts, ice-storms and insect pests and diseases outbreaks. But today all these threats shifting aside by the result of human activities and the global climate change making forest ecosystems more vulnerable for damage. Among forest threats are natural and human-induced once. Major natural forest threats are natural destructive wild fires, climate change, insect pests and diseases epidemics, loss of plant biodiversity. Anthropogenic drivers are considered: overexploitation, human induced fires, invasive plant species, illegal loggings, non-sustainable forest management, agricultural expansion, infrastructure development, enlargement of towns [5,7]. From natural threats such as wild destructive fires and outbreaks of insect pests and diseases are the integral part of forests dynamics, however they disrupt the yields of forests goods and services, affecting growth of trees and their survival, as well as water quality and biodiversity. Among the major challenges of forest threats in many countries are outbreaks of insect pests and diseases resulting in economic and environmental resources lost. When insect outbreaks reach epidemic, covering large territories and lasting for months, aerial resources of fight remain the only way to treat the infestation effectively and protect valuable forests. In Tables 3-5 are given the materials of damage from insects and diseases according to forest species from 25 countries, forests areas affected by continents and forest areas affected by insect pests and diseases by climatic zones $[8,9]$. Planted forests are more affected by insect pests and diseases than naturally regenerated forests. As to the plant species, broadleaves are affected more than coniferous (Table 3). According to the continents the most affected are: Europe-941,992ha., Followed by North and Central America738,287ha and South America-612,358 ha. (Table 4). By climate zones the most affected is temperate zone- 72, 616ha. Then come tropical zone- 10,676ha. and subtropical-7,814ha (Table 5).

Table 4: Forest area affected by insect pests and diseases by continents (ha).

\begin{tabular}{|c|c|c|c|}
\hline Region & Forest area & Insect pests & Diseases \\
\hline Africa & 104 & 9,518 & 1,042 \\
\hline Asia & 399,796 & 7,406 & 5,251 \\
\hline Europe & 941,992 & 10,449 & 4,681 \\
\hline North and Central America & 738,287 & 57,024 & 1,260 \\
\hline Oceania & 10,158 & 2 & 196 \\
\hline South America & 612,358 & 10,356 & 24 \\
\hline Total & $2,806,983$ & 85,120 & 12,454 \\
\hline
\end{tabular}

Source: FAO, FRA 2015.

Table 5: Forest area affected by insect pests and diseases by climatic zones (ha).

\begin{tabular}{|c|c|c|c|}
\hline Climatic zone & Insect pests & Diseases & Total \\
\hline Boreal & 3,702 & 3,165 & 6,867 \\
\hline Temperate & 69,582 & 3,034 & 72,616 \\
\hline Subtropical & 2,619 & 5,195 & 7.814 \\
\hline Tropical & 9,616 & 1,060 & 10,676 \\
\hline Total & 85,518 & 12,454 & 97,972 \\
\hline
\end{tabular}

Source: FAO, FRA 2015.

Table 6: Average area of forest annually affected by fire by regions and sub-regions, 2005.

\begin{tabular}{|c|c|c|c|c|}
\hline \multirow{2}{*}{ Region/Sub-region } & \multicolumn{2}{|c|}{ Information availability } & \multicolumn{2}{c|}{ Area of forest affected by fire } \\
\cline { 2 - 5 } & Number of countries & \% of total Forest area & $\mathbf{1 0 0 0}$ hectare & \% of forest area \\
\hline Eastern and Southern Africa & 8 & 29.3 & 452 & $0-6$ \\
\hline Northern Africa & 5 & 10 & 17 & 0.2 \\
\hline Western and Central Africa & 8 & 19.7 & 7,849 & 5.4 \\
\hline Total Africa & 21 & 22.4 & 8,318 & 0.2 \\
\hline East Asia & 5 & 100 & 549 & 0.7 \\
\hline South and South-East Asia & 8 & 83.3 & 1,859 & 0.2 \\
\hline Western and Central Asia & 16 & 51.7 & 2,457 & 0.5 \\
\hline Total Asia & 29 & 87.9 & 270 & 0.1 \\
\hline Europe excl. Russia & 41 & 96.6 & 1,262 & 0.1 \\
\hline Total Europe & 42 & 99.4 & 15 & 0.3 \\
\hline Caribbean Islands & 7 & 74.1 & 107 & 0.7 \\
\hline Central America & 4 & 72.6 & & \\
\hline
\end{tabular}




\begin{tabular}{|c|c|c|c|}
\hline North America & 4 & 100 & 3,437 \\
\hline Total North and Central America & 15 & 98.9 & 3,558 \\
\hline Total Oceania & 6 & 82.5 & 3,903 \\
\hline Total South America & 5 & 14 & 333 \\
\hline World & 118 & 65.2 & 19,831 \\
\hline
\end{tabular}

Source: FAO Meeting on Public Policies Affecting Forest Fires. FAO, Forestry Paper 138. Rome [20].

Potential costs of US $\$ 540$ billion economic damage to the world agriculture is predicted per year if spread of invasive pests and pathogens won't be stopped. Wildfires are among the most destructive threats to forests. Fires do not respect national boarders among countries. Fast and effective detection is a key factor in wildfire fighting. The four major natural causes of wildfire ignitions are: lightning, volcanic eruption, sparks from rock-falls and spontaneous combustion [10-12]. Wildfires occur on all continents of the world except Antarctica. Destructive wildfires are common events in Australia, Indonesia, USA, Russia and other countries. In the United States there are from 60 to 80 thousand wildfires each year, burning from 3 to 10 million acres of forest land depending on the year. By world regions Western and Central Africa is leading-11.9\% of forest area affected by forests. Then comes Oceania. According to the 2014 data of IPCC Fifth Assessment Report annually wildfires burn around 340 million hectares of the earth's vegetative surface. Wildfires can cause extensive damage both to property and human life, as well as to have negative ecological affects. The most common cause of wild fires differs from country to country. In some countries, for example, lightning is the major factor of wildfire ignition. In other parts of the world human factor is a major contributor [13-16]. But human carelessness is considered a major cause. Tourism and hiking are also great contributors such as: un-extinguished campfire sparks from cars and casting away of cigarette butts. According to Table 6 in 2005 about 20 million hectares of world forest area have been affected by wildfires, that is $0.7 \%$.
Another great threat for forests is invasive species, such as: pests, microorganisms, animals etc. Our interest are invasive plants whose introduction causes economic and environmental damage. Such invasive species can disrupt local ecosystems by dominating particular region, wilderness areas, habitats and suburban-urban interface land by loss of natural controls $[17,18]$. The common invasive species traits include fast growth; rapid reproduction; high dispersal ability; phenotypic plasticity; tolerance of a wide range of environmental conditions. Biotic invasion is considered one of the five top drivers for global biodiversity loss and is increasing because of tourism and globalization. Invasive species may drive local native species to extinction via competitive exclusion niche displacement, hybridization with related native species. Therefore, besides their economic ramifications, alien invasions may result in extensive changes in the structure, composition and global distribution of the biota of sites of introduction, leading to the loss of biodiversity [19-21]. Among top ten invasive families are leading Daisy and Grass families and then comes Legume Family (Table 7). Estimated damage and control cost of invasive species in the U.S. alone is more than $\$ 138$ billion annually. Economic damage can also occur by loss of recreation and tourism revenues. Forage loss from invasion weeds on pastures also amounts to about \$one billion in U.S. only. Many invasive weeds compete with native forage plants and threaten young cattle. 6,075 species are now documented in the world as invasive. Invasive species today are considered among the most important drivers of biodiversity loss.

Table 7: The top ten invasive families of plant species that were the subject of control methods in natural ecosystems.

\begin{tabular}{|c|c|c|c|}
\hline Plant family (N=226) & Common name & Number of spec-ies(N=6,075) & $\begin{array}{c}\text { Number of co-ntrol methods (N } \\
\mathbf{7}\end{array}$ \\
\hline Compositae & Daisy family & 650 & 90 \\
\hline Peaceae & Grass family & 649 & 146 \\
\hline Fabaceae & Legume family & 477 & 40 \\
\hline Rosaceae & Rose family & 290 & 7 \\
\hline Brassicaceae & Mustard family & 219 & 16 \\
\hline Lamiaceae & Mint family & 173 & 3 \\
\hline Amaranthaceae & Amaranth family & 163 & 12 \\
\hline Caryophyllaceae & Pink family & 139 & 4 \\
\hline Cyperaceae & Sedge family & 131 & 7 \\
\hline
\end{tabular}

Source: State of World's Plants 2017. Royal Botanic Gardens Kew. pp.58-63. https:// state of the world's plants org./2017/invasive plants.

\section{Conclusion}

Forests Played a major role throughout the human history in supporting livelihoods and providing food security and nutritional needs of the global population. Our ancestors used wood for cooking, warming and building. Forests increased destruction began from the middle centuries and reached its peak from the second part of $20^{\text {th }}$ century. Increasing level, the world's population, industrialization, tourism, enlargement of towns, infrastructure 
projects and other factors adversely influence on biodiversity and forest loss. The loss of biodiversity and forest cover is considered today as one of the major problems of climate change. Loss of forest cover along with industrial and transportation emissions increase greenhouse effects and threaten all living organisms on earth. In spite of many international conferences and symposiums trying to insure world's governments to reduce greenhouse gasses and stop forests overexploitation this process is continued and there is no force to stop it. We believe that the only way to restrain the appetites of the countries noticed in overexploitation rates and destruction of their forests is that all non-governmental natureprotecting organizations together, under the auspices of FAO, must work out some quotas on forest loggings, especially on those countries as Russia, Canada, U.S. and others that are distinguished by overexploitation and deforestation. Other countries must launch moratorium for several decades to give forests time to recover. This process must proceed under strict control and monitoring and in case of violation must be imposed strong economic sanctions.

\section{References}

1. Bhaskar Vira, Christian Wildburger, Steohanie Mansorian (2015) Forests, Trees and Landscapes for Food Security and Nutrition. Global Assessment Report. IUFRO world Series, Viena, Austria 33: 172.

2. Saastamoinen $O$ (1999) Forest policies, access rights and non-wood forest products in northern Europe. Unasylva 50(198): 20-26.

3. J Anderson, K Warner, L Russo, H Qwist Hoffman (1999) The Challenges of extension for non-wood forest products. Unasylva.

4. Aju PC (2014) The Role of Forestry in Agriculture and Food Security. American journal of research communication 2(6): 109-121.

5. Grainger A, Keenan R, Reams GA, Achard F, Freitas F, et al. (2015) Dynamics of global forest area: results from the FAO Global Forest Resources Assessment. 352: 9-20.
6. Rhett A Butler (2005) World Deforestation rates and forest cover statistics.

7. Van Lierop P, Lindquist Eric, Salhyapala Shiroma, Franceschini Gianluca (2015) Global forest area disturbance from fire, insect pests, diseases and severe weather events. Forest Ecology and Management 352: 78-88.

8. Non-wood forest products for rural income and sustainable forestry (1995) FAO, Non-wood forest products.

9. The global forest resources assessment (2011) FAO.

10. (2008) The United Nation Collaborative Program on Reducing Emissions from Deforestation and Forest Degradation (REDD) in Developing Countries.

11. (1992) The United Nations Framework Convention on Climate Change Chapter XXVII. Environment, p. 7.

12. Brundtland GH (1987) Our common future. Oxford University Press. New York, USA, pp. 300.

13. Deforestation-Modern day Plague (2019) National Geographic.

14. (2000) The fifth national communication from the European community under the UN Framework Convention on Climate Change.

15. (2016) First annual report on the state of the world's plants released by the Royal Botanical Gardens Kew) (U.K.) FAO.

16. State of the world's plants (2017) Royal Botanical Gardens Kew, UK.

17. (2014) IPCC Fifth Assessment Report: Climate Change (AR5).

18. (2017) World Economic Forum/Global Shapers Survey. Annual Survey.

19. UNFCCC (2017) Greenhouse Gas Inventory Data.

20. FAO Meeting on Public Policies Affecting Forest Fires (2010) FAO, Forestry paper 138, Rome. Italy.

21. FAO (2009) Global Review of Forest Pests and Diseases. FAO, Forestry Paper 156. Rome, Italy.
This work is licensed under Creative Commons Attribution 4.0 License

To Submit Your Article Click Here: Submit Article

DOI: $10.32474 /$ CIACR.2019.06.000236

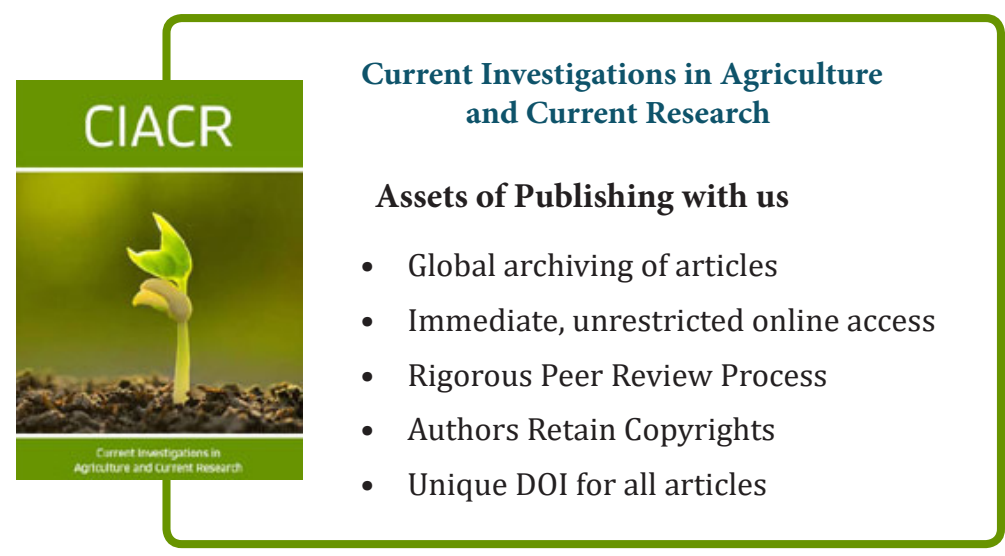

